\title{
Chain of Custody Implementation on Public Service Administration in Indonesia: A Framework
}

\author{
Resista Vikaliana ${ }^{1 *}$, Maya Puspita Dewi2 ${ }^{2}$ Munir Saputra ${ }^{3}$, Tulus \\ Santoso $^{3}$, \& Sukarni Novitasari ${ }^{3}$ \\ ${ }^{1}$ Fakultas Ilmu Sosial dan Manajemen, Institut Ilmu Sosial dan Manajemen Stiami, \\ Indonesia \\ 2Fakultas Ekonomi dan Bisnis, Universitas Esa Unggul, Indonesia \\ ${ }^{3}$ Fakultas Ilmu Administrasi, Institut Ilmu Sosial dan Manajemen Stiami, Indonesia
}

\begin{abstract}
Abstrak Proses administrasi dapat dilihat melalui proses umum, sedangkan tindakan administratif dapat dilihat pada tingkat program tertentu. Chain of custody $(\mathrm{CoC})$, dalam konteks hukum, mengacu pada dokumentasi kronologis atau jejak kertas yang mencatat urutan penahanan, kontrol, transfer, analisis, dan disposisi bukti fisik atau elektronik. Dalam proses layanan, CoC berfungsi untuk melacak dokumen layanan atau jejak dokumen sesuai dengan prosedur yang ditentukan. Dalam pelayanan publik, kegiatan administrasi dilakukan untuk mengendalikan upaya instansi pemerintah agar tujuannya tercapai. Makalah ini bertujuan untuk mengkaji penerapan CoC dalam penyelenggaraan pelayanan publik di Indonesia. Berdasarkan pendekatan kuasi-kualitatif yang dilakukan, diperoleh kesimpulan bahwa penerapan CoC dalam penyelenggaraan pelayanan publik dapat memberikan kerangka kerja yang berguna untuk memahami dan meningkatkan upaya pengurangan masalah administrasi dalam pelayanan publik.
\end{abstract}

Kata kunci: chain of custody / CoC; administrasi; layanan publik; implementasi; kerangka kerja

\begin{abstract}
Administrative processes can be seen through a general process, while administrative action can be examined at a certain program level. Chain of custody $(\mathrm{CoC})$, in the context of law, refers to chronological documentation or paper traces that record the sequence of detention, control, transfer, analysis, and disposition of physical or electronic evidence. In the service process, the CoC serves to track service documents or document traces according to the procedures specified. In public services, administrative activities are carried out to control the efforts of government agencies so that their objectives are achieved. This paper aims to examine the application of $\mathrm{CoC}$ to the administration of public services in Indonesia. Based on the quasi-qualitative approach taken, it was produced that the application of $\mathrm{CoC}$ to the administration of public services can provide a useful framework for understanding and improving efforts to reduce administrative problems in public services.
\end{abstract}

Keywords: chain of custody / CoC; administration; public services; implementation; framework

JEL Classification: A1O; $H 830$ 


\section{INTRODUCTION}

The advancement of information and communication technology (ICT) is driving digital transformation that can create new values for policies in many countries. The development of digital technologies such as artificial intelligence (AI), Internet of Things (loT), artificial intelligence ( $\mathrm{Al}$ ) and robotics causes significant changes to the environment and people's values. Changes in the environment and community values are becoming increasingly diverse and complex.

The development of technology, namely the industrial revolution 4.0 is a good opportunity to carry out the functions and roles of government organizations more effectively. Digital technology can accelerate the implementation of e-governance, especially in the digitization of data and information. In line with the Government's main task of conducting Public Services, one of its actualization is the implementation of e-public services, namely the change from conventional services to digital services has become a necessity. This demand is considered as one indicator of modern governance that is fast, precise, and efficient.

This phenomenon is an implication of the rapid changes in the field of information technology which now brings world civilization to face an era better known as the industrial era 4.0. This era is characterized by the virtual world and digital systems which are the main modes of human interaction. Technological innovation enables the redistribution and decentralization of power so that the Government will increasingly face pressure to change the approach used to involve the public in policy making. The government returns to the basics by fixing human resources, infrastructure and regulation. Regulations must be flexible or flexible in order to adapt to the changes that are taking place, including in terms of public services.

Digital governance in public services as revealed by Dunleavy (2006) when introducing the concept of digital governance suggests that various technologyrelated changes are very important for current and subsequent changes. In public service, the New Public Service is considered as an effort to criticize the Old Public Administration and New Public Management paradigms which are considered not to have a welfare effect and instead spread injustice in providing services to the public. The public should be regarded as citizens rather than clients or voters as in the Old Public Administration or customer paradigm carried by the paradigm of the New Public Management (Dunleavy \& Margetts, 2006).

The basic principles or assumptions of the New Public Service are as follows:

1. Serving Non-Customer Citizens: through the taxes they pay, citizens are the legitimate owners of countries not customers.

2. Public Interest: public interests are often different and complex, but the state is obliged to fulfill them. The state must not throw its responsibilities to other parties in fulfilling the public interest.

3. More Valuable or Value Citizenship than Entrepreneurship: entrepreneurship is important, but citizens are above all else. 
4. Strategic Thinking and Democratic Actions (Think Strategically, Act Democratically); the government must be able to act quickly and use a dialogue approach in solving public problems.

5. Realize that Accountability Is Not Easy (Recognize that Accountability Isn't Simple); accountability is a difficult and measurable process that must be done with the right method.

6. Serving rather than Directing (Serve Rather than Steer); the main function of the government is to serve citizens rather than direct.

7. Respect for Humans not just Productivity (Value People, Not just Productivity); the interests of the community must be a priority even though it is contrary to the values of productivity.

State that the new public service is more directed at the concepts of democracy, pride / self-esteem, and citizens than the concepts of markets, competition, and customers as those in the private sector (Denhardt \& Denhardt, 2000). The concept of good governance using the term public service is equated with the term public service or community service. Service is a function of the government or the private sector to provide various needs of the community. Normatively, in Indonesia there are several aspects that need to be considered in public services in accordance with the decision of the Minister of Administrative Reform (MENPAN) Number 18/1993, namely: 1 . Simple principles; 2 . the principle of clarity and certainty; 3 . security; 4. the principle of openness; 5 . economic principle; 6 . the principle of justice of service; and 7 . the principle of quality service that is always on time with flawless quality.

Empirically, services that are adjusted to the demands of standards and norms by public organizations still need to be continually improved because so far there has been a tendency for services received by the community to be far from expected. Therefore, the synergy of the governance component in public service needs to be optimized. In the perspective of governance theory, quality public services are the result of synergistic interactions between various actors or institutions. Uphof (in Suwondo, 2000: 4) recommends the involvement of three sectors in providing public services, namely: government / state sector, market) and Non Government Organizations (NGOs)/ Grassroot Organizations/ Civil Institutions.

Dwipayana, et al. (2003) state that There are three reasons to renew public services, so that they can be a driving force for the development of good governance practices in Indonesia. First, improving the performance of public services is considered important by all stakeholders. The stakeholders in question are citizens, government and market players, because interests will be able to increase the prosperity of users and make market mechanisms efficient. can interact intensively between stakeholders in service delivery (civil society, government, and market players. Third, public convenience. Both are values that characterize the practice of public service delivery governance, such as efficiency, fairness, transparency, participation, and accountability ).

The State Minister for State Apparatus Empowerment (MenegPAN) provides a definition of public services as all service activities carried out by public service 
providers as an effort to fulfill the needs of recipients of services and the implementation of statutory provisions.

Law/ Undang-undang Number 25 of 2009 states that public services are activities or series of activities in order to fulfill service needs in accordance with the laws and regulations for every citizen and resident for administrative goods, services and / or services provided by public service providers. Furthermore, the said law regulates the types of public services which include: 1 . public goods services, 2. public services, and 3. administrative services. The scope of the three types of public services is in the fields of education, teaching, employment and business, shelter, communication and information, environment, health, social security, energy, banking, transportation, natural resources, tourism and strategic sectors others.

Some of the problems identified in public service in Indonesia are the low accountability and capacity of public service delivery institutions, and the low level of public participation in supporting the implementation of public services. The administrative process can be seen through a general process, while administrative action can be examined at a certain program level. Chain of custody ( $\mathrm{CoC}$ ), in the context of law, refers to chronological documentation or paper traces that record the sequence of detention, control, transfer, analysis, and disposition of physical or electronic evidence. In the service process, the $\mathrm{CoC}$ serves to track service documents or document traces according to the procedures specified. In public service, administrative activities are carried out to control the efforts of government agencies so that their objectives are achieved, and can also be interpreted as activities carried out to control the efforts of government agencies so that the objectives are achieved.

Procedure: Throughout the investigation, the person in charge of the chain of custody must:

1. Document the location of the incident and the time of arrival at the scene.

2. Determine the preservation of evidence (which agency is responsible for the collection of certain evidence, and determine the collection of evidence)

3. Identify, document, secure, and store evidence properly

4. Document the collection of evidence

5. List of personnel list, list of witnesses, and documentation of time of arrival and departure of personnel.

Maintaining the proper chain of custody for evidence is of paramount importance. The integrity of evidence can be guaranteed through proper documentation, collection and preservation. The challenge to the integrity of the evidence can be reduced if the chain of custody and fast transfers are properly maintained (Houck et al., 2018).

The chain of custody can be a simple paper document filled out by hand and signed by each party in the exchange of evidence. With modern computerized evidence tracking systems, chains can be created electronically using a personal 
identification number (PIN), badge, or other identification device; in the final case, a paper copy can be printed and saved in a hard copy file..

Yasuda et al., (2006) have investigated an effort to reduce people's health problems on seafood consumption. Research conducted by studying the chain from the ocean to the final consumer provides a useful framework for understanding the problem. Meanwhile, J. Cosic (2010) researched the digital evidence management framework (DEMF), which can improve the digital evidence chain at all stages of the digital investigation process. In the proposed framework, it is used as a function for digital fingerprint evidence, biometric characteristics for authentication and personal identification are handled with evidence. Digital trusted test site to determine the exact time when evidence was found or when it was found. accessed to the evidence and GPS coordinates to determine the location of the evidence. Using all these factors in the right way provides a safe and secure chain of custody.

Whereas Prayudi (2014) produces research that shows Chain of Custody (CoC) is the process of tracking, recording and transferring material from certified forests through different stages of the process of upstream industry, downstream industry, agents and to stores or end consumers. The types of activities that have generally begun to be requested include the COC system including the sawmill industry, furniture, wood pellets, pulp and paper, printing, trading (merchants) and textiles.

Based on the state of the art public service described earlier, this study wants to know the administrative process in public service if the chain of custody is applied and proposes a framework..

\section{METHOD}

The approach of this research is quasi qualitative. In-depth interviews were conducted on 2 public service bureaucrats and 3 people who received public services. Qualitative research is applied, because this research is a social research that aims to understand the meaning of individuals and groups as well as explore deeper problems (Djamba \& Neuman, 2002). In addition, document studies and observations were carried out. To test the validity and reliability of this study, an extension of observation and member checking was carried out.

Grindle theory is used as an initial guide to researching this, including proposing a framework. According to Grindle, the success of implementing a public policy can be measured by the process of achieving the end result, namely whether or not the goals to be achieved are achieved (Grindle, 1980). 


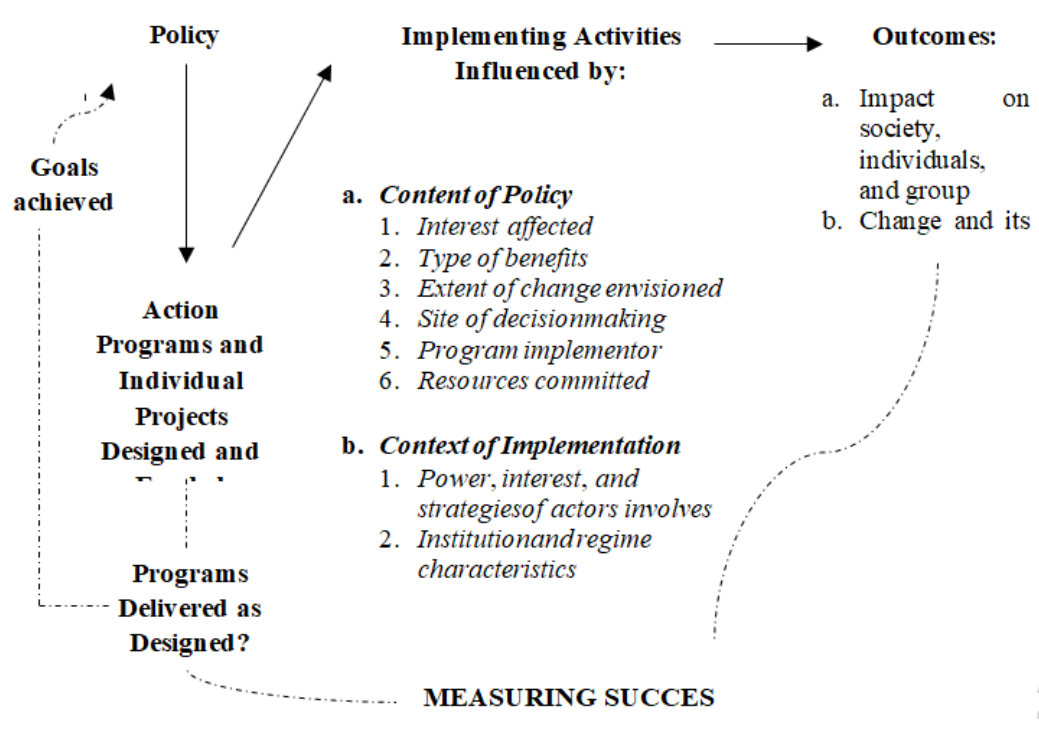

Figure 1. Implementation as a Political and Administrative Process Grindle, (1980)

According to Merilee S. Grindle (1980) that the successful implementation of public policy is influenced by two fundamental variables, namely the policy content (content of policy) and the implementation environment (context of implementation) as shown in the picture above (Grindle, 1980). The variable contents of this policy include:

1. The extent to which the interests of the target group or target groups are contained in the contents of the policy;

2. The types of benefits received by target groups,

3. The extent to which a change is desired from a policy.

4. Is the location of a program correct.

5. Does a policy mention the implementor in detail; and

6. Is a program supported by adequate resources.

While the policy environment variables include:

1. How much power, interests, and strategies do the actors involved in implementing the policy have,

2. Characteristics of institutions and regimes in power,

3. The level of compliance and responsiveness of the target group.

Grindle introduced an implementation model as a political and administrative process. The model describes the decision-making process carried out by various actors, where the final output is determined by both the program material that has been achieved and through the interaction of decision makers in the administrative political context. The political process can be seen through a decision-making process that involves various policy actors, while the administrative process is seen through a general process of administrative action that can be examined at a certain program level. 
Based on the description above, the conceptual model in this study is described in the form of images as follows:

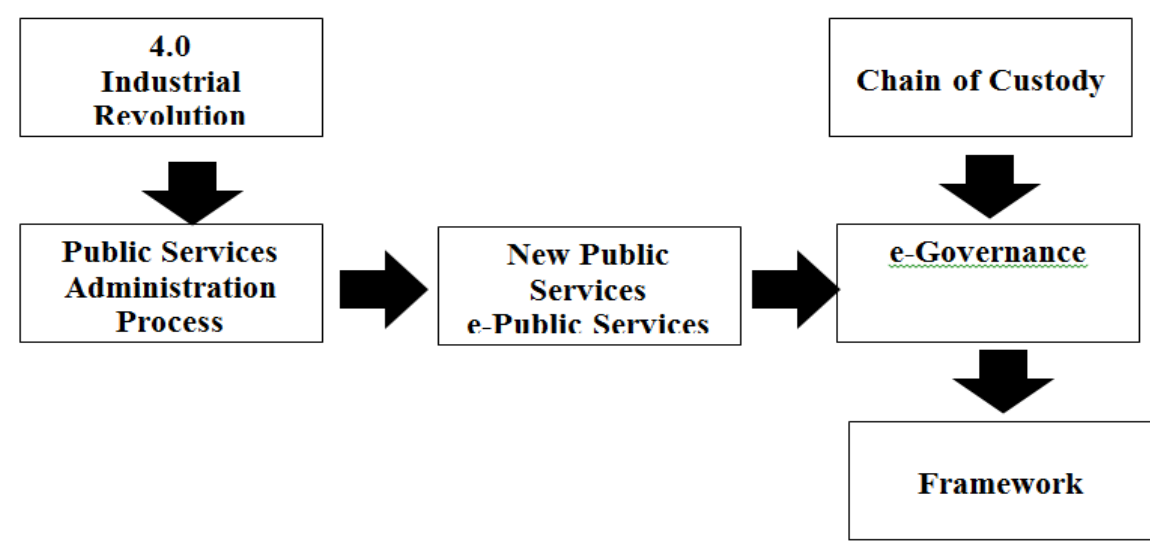

Figure 2. Research Conceptual Model

\section{RESULT AND DISCUSSIONS}

Implementation can begin when the objectives and objects of policy have specificity, when the policy program has been carefully designed, when the funds have been allocated according to the objectives. This is a basic condition for directly executing the public policy process. So that the policy process, the program that is run must be integrated which can determine the success rate of the program.

According to Grindle there are 2 variables that influence the implementation of public policy. Based on the interview results, it can be verified that the inclusion of Human Resources / HR has the greatest potential to be synergized in service. In this section, almost all stakeholders offer contributions to the participation of HR in each stage of the implementation of public services. The application of Chains of custody may be a simple paper document that is filled out by hand and signed by each party in the evidence exchange. With modern computerized evidence-tracking systems, the chain may be created electronically using, so that HR is needed to understand the operation of digital services digitally.

The final results of the study found that in preparing a framework for public service administration, with the implementation of the chain of custody, there are requirements that must be met to effectively implement digital public services, namely the fulfillment of

1. Tracebility to Legal Time Source

2. Time Distribution

3. Source Digital Time Stamping

Basically, the governance component has diverse potential to assist various stages in the implementation of public services. So, the government does not need to take an omnipotent and hegemonic role as the sole ruler who governs everything. 
The potential has been divided into other governance components, so that in exercising their power and authority to provide public services to the public, the government needs to have "the art of steering". That is, the government remains a key player in the implementation of public services, but at the same time, it must have sufficient capacity / capability to mobilize other components of governance to work together to achieve public service goals.

From the results of data collection, it was found that basically the governance component had considerable potential to synergize. However, the lack of communication, coordination and initiation between components of governance causes them to carry out their programs partially without thinking about constructive forms of synergy, even though in reality the program targets intersect with one another. Therefore, communication, coordination and initiation are key words that need to be done in order to optimize the synergy between components of governance in the delivery of public services.

In the perspective of governance theory, quality public services are the result of synergistic interactions between various actors or institutions. The satisfying end result of a public service cannot be achieved if it only relies on one sector. There is no single actor, not even a country, that is able to efficiently, economically and fairly provide various forms of public service independently. From the perspective of governance theory, if the government can improve the quality of the delivery of public services, the benefits can be felt directly by the public and market participants.

\section{CONCLUSION}

Based on the results of the research conducted, it was produced that the application of $\mathrm{CoC}$ to the administration of public services can provide a useful framework for understanding and improving efforts to reduce administrative problems in public services. For this reason, there are requirements that must be met to effectively implement digital public services, namely fulfillment: Tracebility to Legal Time Source, Time Distribution and Source Digital Time Stamping.

\section{DAFTAR PUSTAKA}

(1) Ćosić, J. (2010). A Framework to (Im ) Prove „Chain of Custody “ in, (Im), 435-438.

(2) Houck, M. M., Crispino, F., \& McAdam, T. (2018). The Chain of Custody. The Science of Crime Scenes, 109-119. https://doi.org/10.1016/B978-0-12-849878-1.00012-0

(3) Yasuda, T. (2006). Chain of custody as an organizing framework in seafood risk reduction. Marine Pollution Bulletin, 53(10-12), 640-649. https://doi.org/10.1016/J.MARPOLBUL.2006.08.015

(4) Denhardt, R., \& Denhardt, J. (2000). The New Public Service: Serving Rather Than Steering. Public Administration Review, 549-559. https://doi.org/10.1111/0033$\underline{3352.00117}$ 
(5) Djamba, Y. K., \& Neuman, W. L. (2002). Social Research Methods: Qualitative and Quantitative Approaches. In Teaching Sociology (Vol. 30, Issue 3). https://doi.org/10.2307/3211488

(6) Dunleavy, P., \& Margetts, H. (2006). New Public Management Is Dead — Long Live Digital-Era New Public Management Is Dead — Long Live Digital-Era Governance. Journal of Public Administration Research and Theory, July. https://doi.org/10.1093/jopart/mui057

(7) Dwipayana, A.,. 2003. Membangun Good Governance di Desa. Yogyakarta: IRE Press. Keputusan Menteri Pendayagunaan Aparatur Negara Nomor KEP/26/M.PAN/2/2004 tentangPetunjuk Teknis Transparansi dan Akuntabilitas dalam Penyelenggaraan Pelayanan Publik.

(8) Grindle, Merilee S. 1980. Politics and Policy Implementation in The Third World, Princnton University Press, New Jersey.

(9) Prayudi, Yudi. Ahmad Ashari, Tri K. Priyambodo. Digital Evidence Cabinets: A Proposed Framework Handling Digital Chain of Custody. International Journal of Computer Application. Volume 107 No. 9, December 2014

(10) Suwondo. 2000. Desentralisasi Pelayanan Publik: Hubungan Komplementer antara Sektor Negara, Mekanisme Pasar dan Organisasi Non Pemerintah. Jurnal Ilmiah Administrasi Publik Fakultas IImu Administrasi Universitas Brawijaya Malang, I (2). 